\title{
Correction to: Template-based temporomandibular joint puncturing and access in minimally invasive TMJ surgery (MITMJS) - a technical note and first clinical results
}

Matthias Krause ${ }^{1}$, Hans Martin Dörfler², Daniel Kruber ${ }^{1}$, Heike Hümpfner-Hierl ${ }^{1}$ and Thomas Hierl ${ }^{3^{*}}$

Correction to: Head Face Med

https://doi.org/10.1186/s13005-019-0194-8

Following publication of the original article [1], the authors reported that the registration number of the ethics approval was accidentally entered under trial registration. A trial registration was not performed by the authors.

\section{Author details}

'Department of Oral \& Maxillofacial Plastic Surgery, Leipzig University, Liebigstr. 12, 04103 Leipzig, Germany. ${ }^{2}$ Faculty of Mechanical and Energy Engineering, University of Applied Sciences (HTWK), Karl-Liebknecht Str. 145, 04277 Leipzig, Germany. ${ }^{3}$ Department of Oral and Maxillofacial Plastic Surgery, Helios Vogtlandklinikum Plauen, Roentgenstr. 2, 08529 Plauen, Germany.

Published online: 18 June 2019

\section{Reference}

1. Krause M, Dörfler HM, Kruber D, Hümpfner-Hierl H, Hierl T. Template-based temporomandibular joint puncturing and access in minimally invasive TMJ surgery (MITMJS) - a technical note and first clinical results. Head Face Med. https://doi.org/10.1186/s13005-019-0194-8.

\footnotetext{
* Correspondence: Thomas.Hierl@helios-gesundheit.de

${ }^{3}$ Department of Oral and Maxillofacial Plastic Surgery, Helios

Vogtlandklinikum Plauen, Roentgenstr. 2, 08529 Plauen, Germany

Full list of author information is available at the end of the article
}

(c) The Author(s). 2019 Open Access This article is distributed under the terms of the Creative Commons Attribution 4.0 International License (http://creativecommons.org/licenses/by/4.0/) which permits unrestricted use, distribution, and reproduction in any medium, provided you give appropriate credit to the original author(s) and the source, provide a link to the Creative Commons license, and indicate if changes were made. The Creative Commons Public Domain Dedication waiver (http://creativecommons.org/publicdomain/zero/1.0/) applies to the data made available in this article, unless otherwise stated. 